\title{
Birds of Bukit Timah Nature Reserve, Singapore
}

\author{
K.S. Lim \\ Nature Society (Singapore), \\ 510 Geylang Road, The Sunflower \#02-05, \\ 389466 Singapore \\ ibisbill@yahoo.com
}

\begin{abstract}
A survey of birds in Bukit Timah Nature Reserve (BTNR), Singapore, in 20152016 yielded a cumulative total of 1663 individual sightings, amounting to 68 species. The total ever recorded for BTNR is now 146 bird species. The 68 species recorded in the present survey included four globally threatened, six globally near-threatened species, 14 nationally threatened and six nationally near-threatened species. Few of the species are entirely and strictly forest dependent, though many make use of both primary and disturbed forest environments.
\end{abstract}

Keywords: Avian conservation, biodiversity, monitoring, surveys.

\section{Introduction}

Bukit Timah Nature Reserve (BTNR) is one of the two nature reserves located in the centre of Singapore, set aside to conserve the country's last remaining hill and lowland rain forests. Collectively, BTNR and the Central Catchment Nature Reserve (CCNR) are known as the "central forests" and protect indigenous rainforest animals and plants in an area of approximately 3206 ha. Deforestation, hunting and fragmentation since the nineteenth century have led to the extirpation of many indigenous species, including at least 70 bird species (Lim, 1992, 1997). The comprehensive biodiversity survey of the 163 ha Bukit Timah Nature Reserve (BTNR) has been introduced by Chan \& Davison (2019).

The last comprehensive bird survey of the forests of Bukit Timah Nature Reserve was conducted between July 1996 and June 1997 (Lim, 1997). This was organised by the National Parks Board and carried out by volunteers from the Nature Society (Singapore)'s Bird Group, resulting in 114 species being detected in the survey. The survey also increased the number of birds ever recorded from BTNR from 117 species to 143 species, an increase of $22 \%$, most of the additions being forest margin, parkland and open country species (Lim, 1997).

The closure of BTNR from September 2014 to October 2016 was an opportune time to update and re-evaluate the status of the birds of BTNR with comparison to the data collected in 1997. Four transects were selected and counted monthly by experienced observers for a period of one year, from April 2015 to March 2016. 


\section{Methodology}

Four transects were selected, viz. Summit Road, Cave Path, South View Path and Lasia Track (Fig. 1). Each transect was approximately $1 \mathrm{~km}$ long and birds detected either aurally or visually were counted once each month for 12 months. Counts started at 07.30 am and were completed by 08.30 am by different observers working simultaneously. Total survey effort, time of day and weather conditions were therefore similar for all four transects. Results were tabulated using a simple Microsoft Excel spreadsheet. Counts of individuals were cumulative and do not represent the absolute number of individuals occurring. Species names follow the online resource published by Lim (2018).

\section{Results}

A total of 68 species of bird was recorded (Table 1). These included 14 nationally threatened and six nationally near-threatened species. It also included four globally threatened and six globally near-threatened species (Lim et al., 2008).

The 14 nationally threatened species include Red Junglefowl Gallus gallus, Changeable Hawk-Eagle Nisaetus cirrhatus, Thick-billed Green Pigeon Treron curvirostra (Fig. 2), Violet Cuckoo Chrysococcyx xanthorhynchus, Rusty-breasted Cuckoo Cacomantis sepulcralis, Drongo Cuckoo Surniculus lugubris, Plume-toed Swiftlet Collocalia affinis, Blue-eared Kingfisher Alcedo meninting, Blue-rumped Parrot Psittinus cyanurus, Blue-crowned Hanging Parrot Loriculus galgulus, Straw-headed Bulbul Pycnonotus zeylanicus (Fig. 3 ), Asian Red-eyed Bulbul Pycnonotus brunneus, Greater Green Leafbird Chloropsis sonnerati and Lesser Green Leafbird Chloropsis cyanopogon.

The six nationally near-threatened species include Chestnut-bellied Malkoha Phaenicophaeus sumatranus, Red-crowned Barbet Megalaima rafflesii (Fig. 4), Cream-vented Bulbul Pycnonotus simplex, Asian Fairy-bluebird Irena puella, Common Hill Myna Gracula religiosa and Blue-winged Leafbird Chloropsis cochinchinensis.

Of the 68 species, four were considered globally threatened. These include Straw-headed Bulbul Pycnonotus zeylanicus, Javan Myna Acridotheres javanicus, Brown-chested Jungle-flycatcher Cyornis brunneatus (Fig. 5) and Greater Green Leafbird Chloropsis sonnerati.

Another six species are considered globally near-threatened, viz. Chestnut-bellied Malkoha Phaenicophaeus sumatranus, Red-crowned Barbet Megalaima rafflesii, Blue-rumped Parrot Psittinus cyanurus, Long-tailed Parakeet Psittacula longicauda (Fig. 6), Short-tailed Babbler Malacocincla malaccensis and Lesser Green Leafbird Chloropsis cyanopogon.

Of the 68 species detected during the survey, $57(84 \%)$ are resident, ten $(15 \%)$ are either winter visitors or passage migrants and one $(1 \%)$ is a non-breeding visitor. 


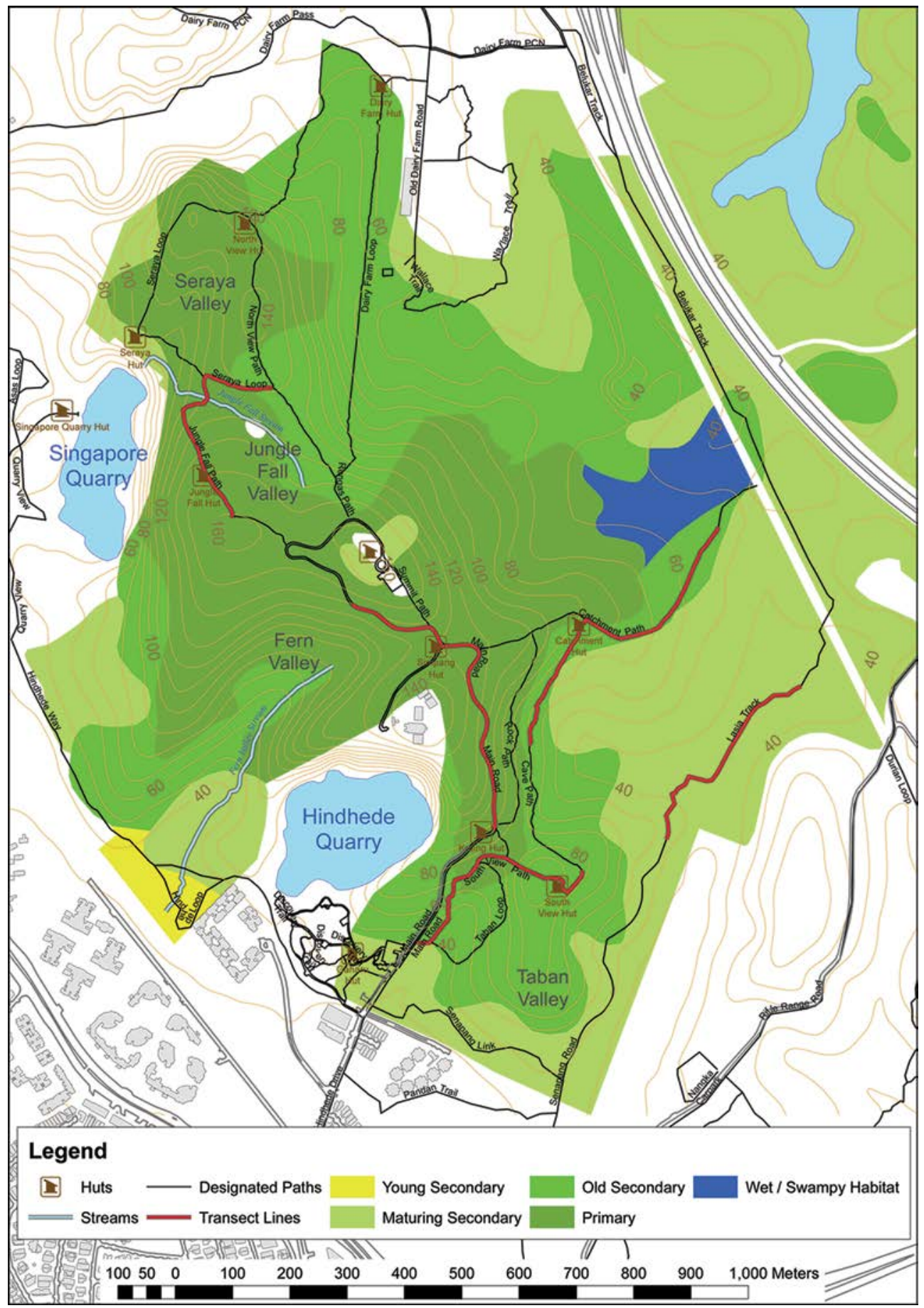

Fig. 1. Map of Bukit Timah Nature Reserve showing the four transects employed. (Source: NParks) 
Table 1. Distribution of species recorded at Bukit Timah Nature Reserve, 2015-2016.

\begin{tabular}{|c|c|c|c|c|c|c|}
\hline Species & $\mathbf{A}$ & B & $\mathbf{C}$ & D & Status & No. \\
\hline Red Junglefowl Gallus gallus** & & + & + & + & $\mathrm{R}$ & 8 \\
\hline Changeable Hawk-Eagle Nisaetus cirrhatus $* *$ & + & + & + & + & $\mathrm{R}$ & 18 \\
\hline Japanese Sparrowhawk Accipiter gularis & + & & & & $\mathrm{R}$ & 1 \\
\hline White-bellied Sea Eagle Haliaeetus leucogaster & + & & & & $\mathrm{R}$ & 6 \\
\hline White-breasted Waterhen Amaurornis phoenicurus & & & & + & $\mathrm{R}$ & 1 \\
\hline Common Emerald Dove Chalcophaps indica & + & + & & + & $\mathrm{R}$ & 5 \\
\hline Pink-necked Green Pigeon Treron vernans & & & + & + & $\mathrm{R}$ & 20 \\
\hline Thick-billed Green Pigeon Treron curvirostra** & + & & & & $\mathrm{R}$ & 4 \\
\hline Greater Coucal Centropus sinensis & & & & + & $\mathrm{R}$ & 3 \\
\hline Lesser Coucal Centropus bengalensis & & & & + & $\mathrm{R}$ & 1 \\
\hline Chestnut-bellied Malkoha Phaenicophaeus sumatranus*\# & & & + & + & $\mathrm{R}$ & 6 \\
\hline Violet Cuckoo Chrysococcyx xanthorhynchus** & + & + & & & $\mathrm{R}$ & 4 \\
\hline Banded Bay Cuckoo Cacomantis sonneratii & + & + & & + & $\mathrm{R}$ & 5 \\
\hline Plaintive Cuckoo Cacomantis merulinus & + & & & + & $\mathrm{R}$ & 3 \\
\hline Rusty-breasted Cuckoo Cacomantis sepulcralis** & & + & & & $\mathrm{R}$ & 1 \\
\hline Drongo Cuckoo Surniculus lugubris** & + & + & + & + & $\mathrm{R}$ & 15 \\
\hline Plume-toed Swiftlet Collocalia affinis ${ }^{* *}$ & + & & & & $\mathrm{R}$ & 1 \\
\hline "Pale-rumped Swiftlets" Collocalia spp. & + & & + & & $\mathrm{R}$ & 26 \\
\hline Oriental Dollarbird Eurystomus orientalis & & & & + & $\mathrm{R}$ & 6 \\
\hline Blue-eared Kingfisher Alcedo meninting** & & + & & & $\mathrm{R}$ & 1 \\
\hline Blue-throated Bee-eater Merops viridis & & + & & + & $\mathrm{R}$ & 2 \\
\hline Lineated Barbet Megalaima lineata & + & & + & & $\mathrm{R}$ & 2 \\
\hline Red-crowned Barbet Megalaima rafflesii*\# & & + & & + & $\mathrm{R}$ & 3 \\
\hline Banded Woodpecker Chrysophlegma miniaceum (Fig. 11) & + & + & + & + & $\mathrm{R}$ & 45 \\
\hline
\end{tabular}


Table 1. Continuation.

\begin{tabular}{|c|c|c|c|c|c|c|}
\hline Species & $\mathbf{A}$ & B & $\mathbf{C}$ & D & Status & No. \\
\hline Common Flameback Dinopium javanense & & + & + & + & $\mathrm{R}$ & 5 \\
\hline Rufous Woodpecker Micropternus brachyurus & & + & + & & $\mathrm{R}$ & 2 \\
\hline Blue-rumped Parrot Psittinus cyanurus**\# & + & & & & $\mathrm{R}$ & 4 \\
\hline Long-tailed Parakeet Psittacula longicauda\# & + & & & + & $\mathrm{R}$ & 4 \\
\hline Blue-crowned Hanging Parrot Loriculus galgulus** & + & + & + & + & $\mathrm{R}$ & 8 \\
\hline Tiger Shrike Lanius tigrinus & + & & & & $\mathrm{M}$ & 1 \\
\hline Black-naped Oriole Oriolus chinensis & & & & + & $\mathrm{R}$ & 6 \\
\hline Crow-billed Drongo Dicrurus annectans & & & + & & M & 1 \\
\hline Greater Racket-tailed Drongo Dicrurus paradiseus & + & + & + & + & $\mathrm{R}$ & 196 \\
\hline Straw-headed Bulbul Pycnonotus zeylanicus $* *$ & & + & & + & $\mathrm{R}$ & 5 \\
\hline Black-crested Bulbul Pycnonotus flaviventris & + & & & & $\mathrm{R}$ & 2 \\
\hline Yellow-vented Bulbul Pycnonotus goiavier & & & & + & $\mathrm{R}$ & 5 \\
\hline Olive-winged Bulbul Pycnonotus plumosus & + & + & + & + & $\mathrm{R}$ & 93 \\
\hline Cream-vented Bulbul Pycnonotus simplex* & + & + & + & & $\mathrm{R}$ & 10 \\
\hline Asian Red-eyed Bulbul Pycnonotus brunneus ${ }^{* *}$ & + & + & & + & $\mathrm{R}$ & 16 \\
\hline Cinereous Bulbul Hemixos cinereus & + & + & & + & $\mathrm{V}$ & 4 \\
\hline Barn Swallow Hirundo rustica & & & + & & M & 1 \\
\hline Pacific Swallow Hirundo tahitica & & & & + & $\mathrm{R}$ & 2 \\
\hline Arctic Warbler Phylloscopus borealis & + & + & + & & M & 13 \\
\hline Eastern Crowned Warbler Phylloscopus coronatus & + & + & + & & M & 9 \\
\hline Common Tailorbird Orthotomus sutorius & & & & + & $\mathrm{R}$ & 4 \\
\hline Dark-necked Tailorbird Orthotomus atrogularis & + & + & + & + & $\mathrm{R}$ & 242 \\
\hline Rufous-tailed Tailorbird Orthotomus sericeus & & + & & + & $\mathrm{R}$ & 13 \\
\hline Pin-striped Tit-Babbler Macronous gularis & + & + & + & + & $\mathrm{R}$ & 319 \\
\hline
\end{tabular}


Table 1. Continuation.

\begin{tabular}{|c|c|c|c|c|c|c|}
\hline Species & $\mathbf{A}$ & B & $\mathbf{C}$ & D & Status & No. \\
\hline Short-tailed Babbler Malacocincla malaccensis\# & & + & + & + & $\mathrm{R}$ & 14 \\
\hline White-crested Laughingthrush Garrulax leucolophus & & + & + & & $\mathrm{R}$ & 6 \\
\hline Oriental White-eye Zosterops palpebrosus & & & & + & $\mathrm{R}$ & 5 \\
\hline Asian Fairy-bluebird Irena puella* & + & + & + & + & $\mathrm{R}$ & 53 \\
\hline Asian Glossy Starling Aplonis panayensis & + & + & + & + & $\mathrm{R}$ & 134 \\
\hline Common Hill Myna Gracula religiosa* & + & + & + & + & $\mathrm{R}$ & 45 \\
\hline Javan Myna Acridotheres javanicus\#\# & & & & + & $\mathrm{R}$ & 4 \\
\hline Dark-sided Flycatcher Muscicapa sibirica & + & & & & M & 1 \\
\hline Asian Brown Flycatcher Muscicapa dauurica & + & & + & & M & 4 \\
\hline Brown-chested Jungle Flycatcher Cyornis brunneatus\#\# & & & & + & M & 1 \\
\hline Siberian Blue Robin Larvivora cyane & + & + & & + & M & 12 \\
\hline Greater Green Leafbird Chloropsis sonnerati** & & & + & & $\mathrm{R}$ & 6 \\
\hline Lesser Green Leafbird Chloropsis cyanopogon ${ }^{* * \#}$ & & & + & & $\mathrm{R}$ & 2 \\
\hline Blue-winged Leafbird Chloropsis cochinchinensis* & + & + & + & & $\mathrm{R}$ & 42 \\
\hline Orange-bellied Flowerpecker Dicaeum trigonostigma & + & + & + & & $\mathrm{R}$ & 56 \\
\hline Scarlet-backed Flowerpecker Dicaeum cruentatum & + & + & & + & $\mathrm{R}$ & 8 \\
\hline Brown-throated Sunbird Anthreptes malacensis & + & & + & + & $\mathrm{R}$ & 9 \\
\hline Van Hasselt's Sunbird Leptocoma brasiliana & + & + & + & + & $\mathrm{R}$ & 9 \\
\hline Crimson Sunbird Aethopyga siparaja & + & + & + & + & $\mathrm{R}$ & 83 \\
\hline Little Spiderhunter Arachnothera longirostra & + & + & + & + & $\mathrm{R}$ & 17 \\
\hline Number of species at each transect & 40 & 37 & 34 & 43 & & \\
\hline
\end{tabular}

Key: * - Nationally near-threatened; ** - Nationally threatened; \# - Globally near-threatened; \#\# - Globally threatened.

R- Resident; M- Migrant; V - Non-breeding Visitor.

Transects: A - Summit Road; B - Cave Path; C - South View Path; D - Lasia Track. 


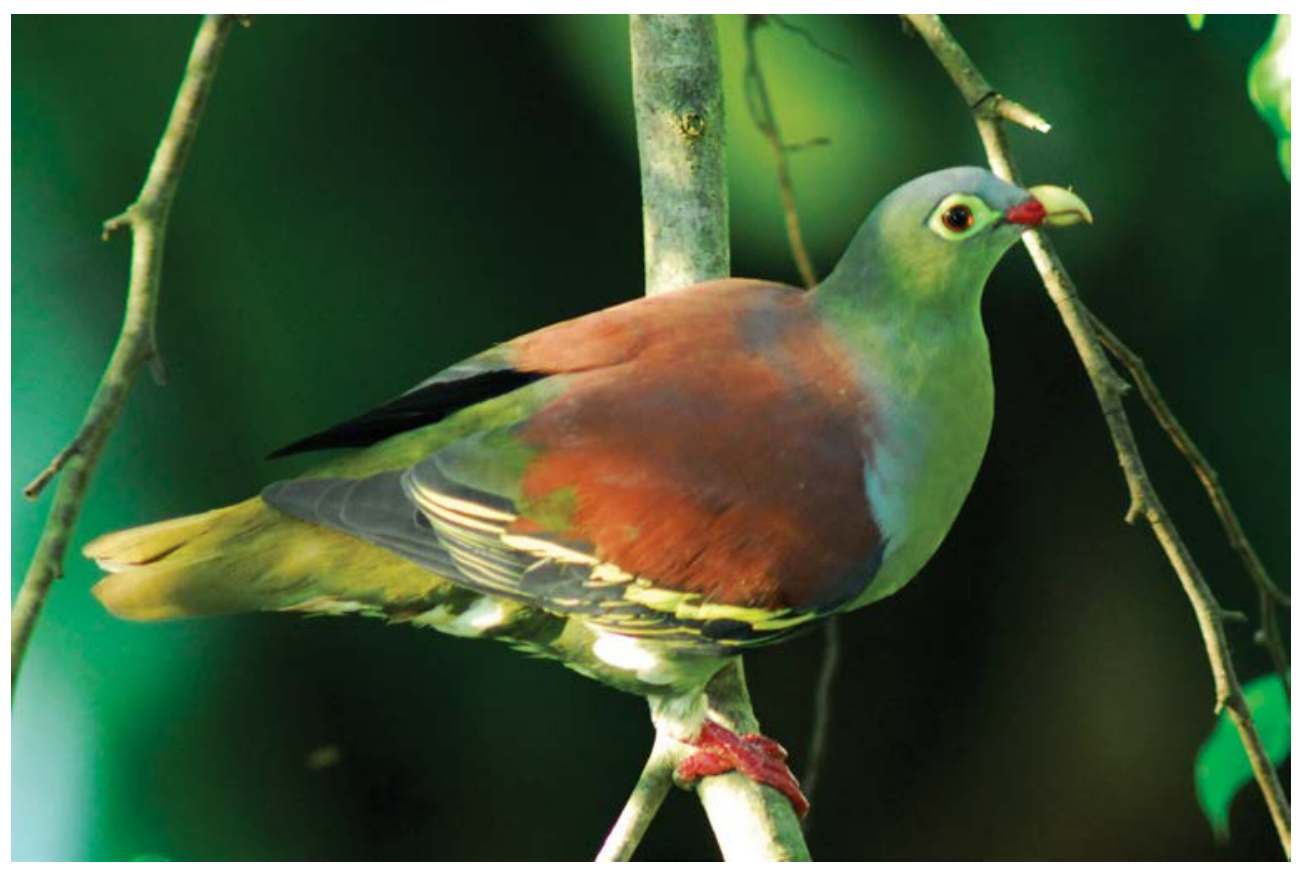

Fig. 2. The Thick-billed Green Pigeon Treron curvirostra is one of the 14 nationally threatened species. (Photo: Y. Cai)

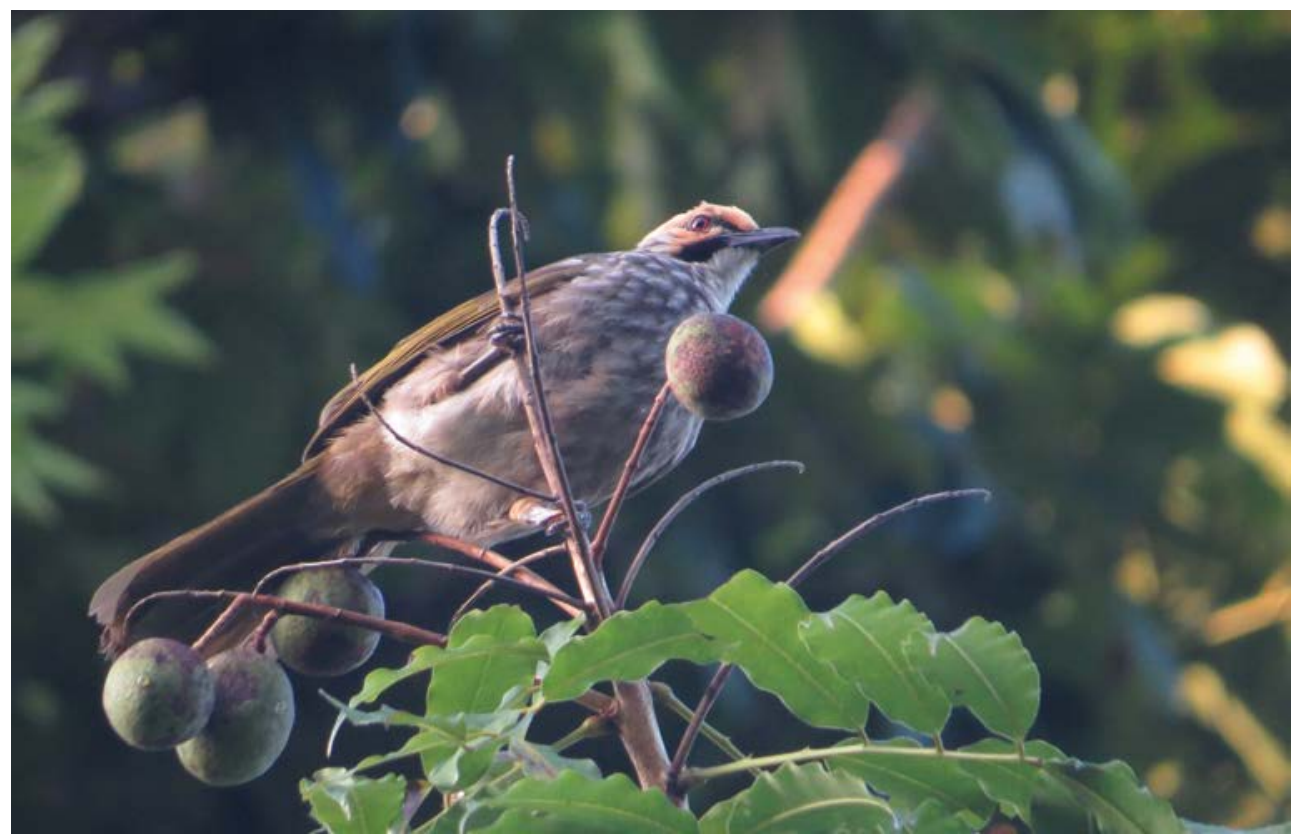

Fig. 3. The Straw-headed Bulbul Pycnonotus zeylanicus has disappeared through most of its range as a result of the cagebird trade. Bukit Timah Nature Reserve represents an important site for its long-term survival (Photo: K.S. Lim). 


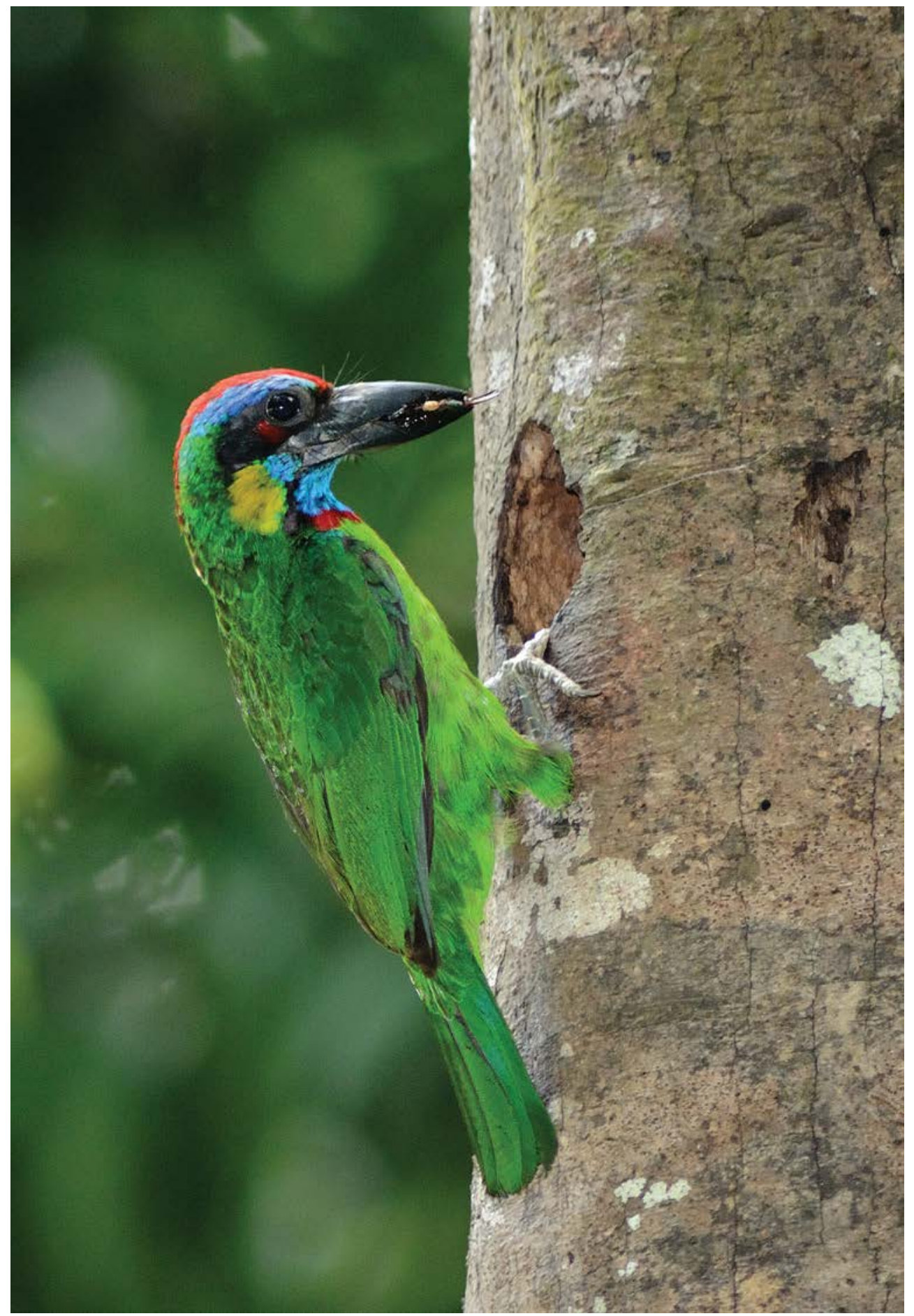

Fig. 4. The colourful Red-crowned Barbet Megalaima rafflesii is both globally and nationally near-threatened. (Photo: Y. Cai) 


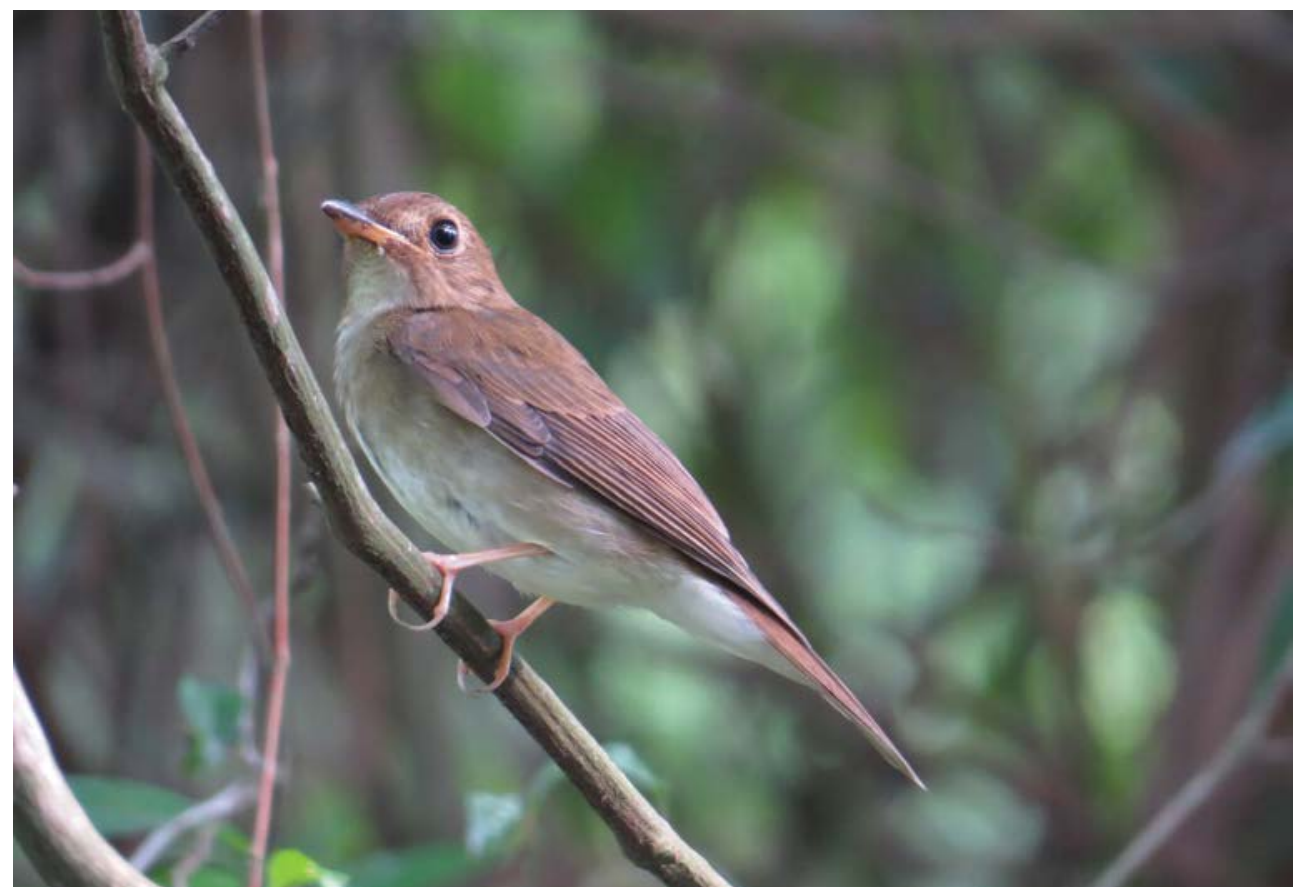

Fig. 5. The Brown-chested Jungle-flycatcher Cyornis brunneatus, rated by IUCN as globally threatened, is a regular visitor, in small numbers, to Bukit Timah Nature Reserve (Photo: K.S. Lim).

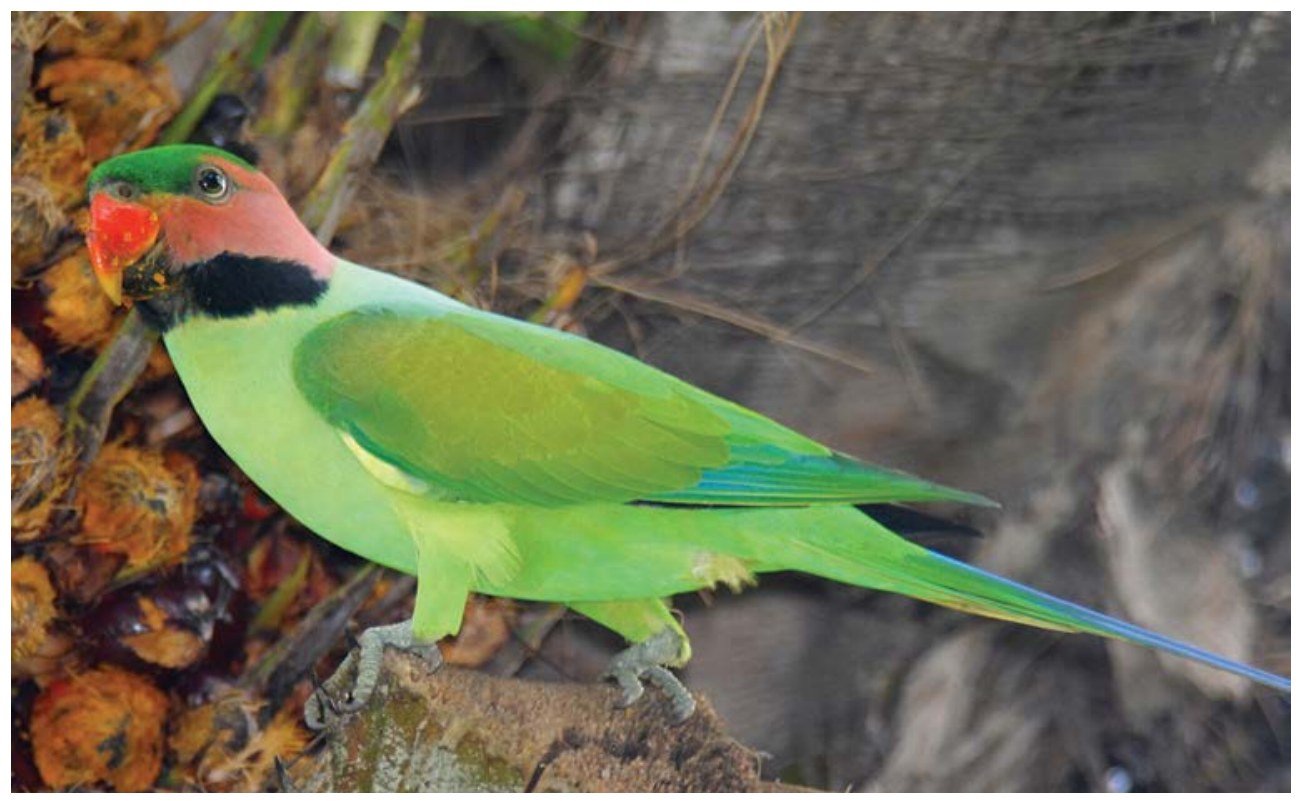

Fig. 6. The Long-tailed Parakeet Psittacula longicauda is globally near-threatened. With breeding recorded, the population appears to be stable. (Photo: Y. Cai) 


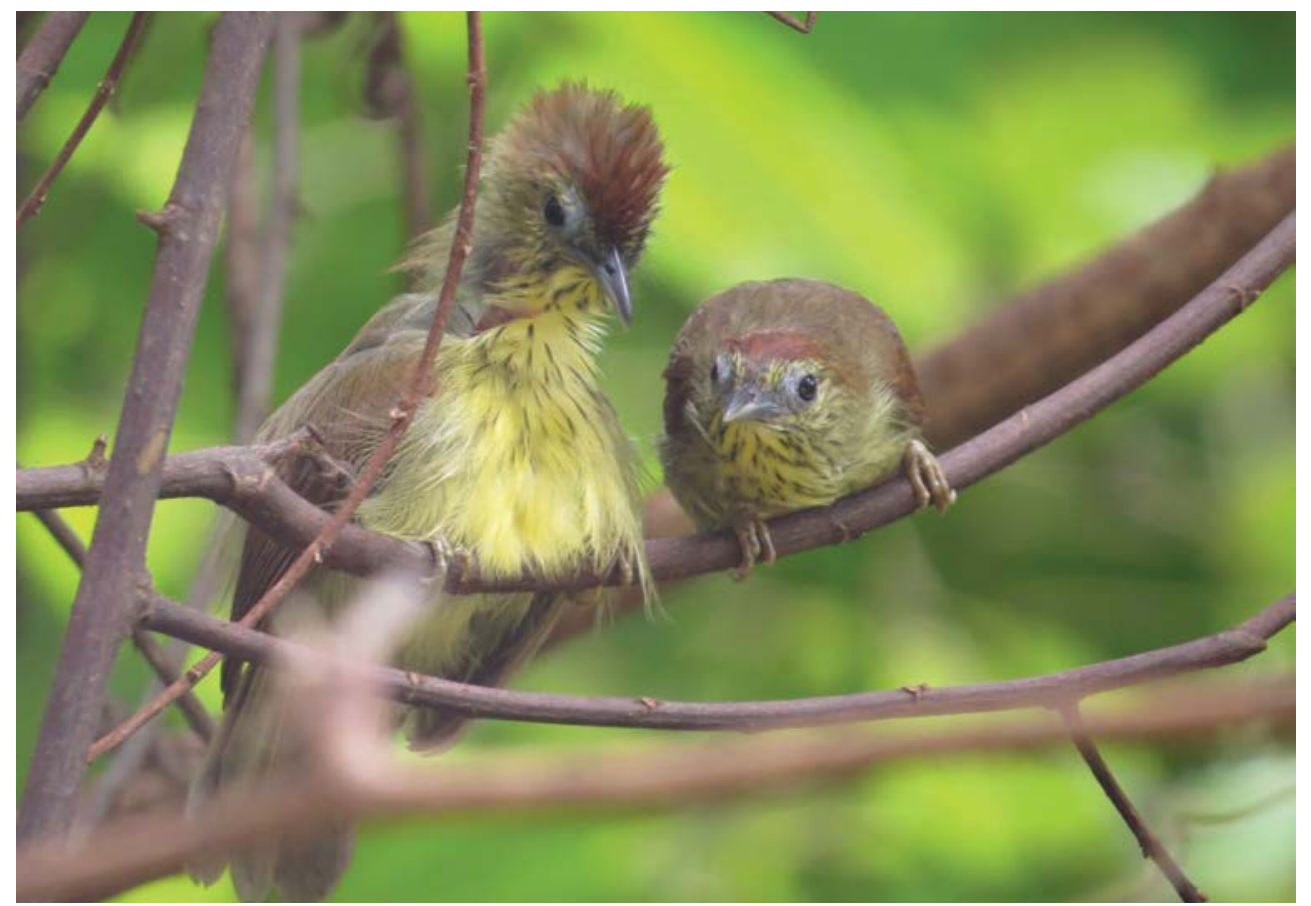

Fig. 7. The Pin-striped Tit-babbler Macronous gularis is the most abundant bird detected during the survey being present in all the transects throughout the survey period (Photo: K.S. Lim).

The top 20 most abundant birds are listed in Table 2. The top five most abundant species recorded included Pin-striped Tit-Babbler Macronous gularis (Fig. 7), Dark-necked Tailorbird Orthotomus atrogularis, Greater Racket-tailed Drongo Dicrurus paradiseus, Asian Glossy Starling Aplonis panayensis and Olive-winged Bulbul Pycnonotus plumosus. This is very similar to the results of the Annual Bird Census (ABC) conducted annually at BTNR by the Nature Society (Singapore) (NSS). Their top six most abundant species from 1997 to 2015 are Asian Glossy Starling Aplonis panayensis, Javan Myna Acridotheres javanicus, Dark-necked Tailorbird Orthotomus atrogularis, Pin-striped Tit-Babbler Macronous gularis, Greater Racket-tailed Drongo Dicrurus paradiseus and Olive-winged Bulbul Pycnonotus plumosus (Table 3). If we remove the opportunistic non-forest sturnids, the top five most abundant species are exactly the same.

Each transect averaged 36 species, with the richest diversity being Lasia Track (43 species), followed by the Summit Road (40 species), Cave Path (37 species) and South View Path (30 species). In terms of abundance, the richest transect was the South View Path with 455 birds counted, followed by the summit road (448 birds), Cave Path (411) and Lasia Track (349). Each transect averaged 416 birds over the survey period. 
Table 2. Top 20 most abundant species recorded at Bukit Timah Nature Reserve, 2015-2016.

\begin{tabular}{|c|c|c|}
\hline Species & Status & Total Counted \\
\hline Pin-striped Tit-Babbler Macronous gularis & $\mathrm{R}$ & 319 \\
\hline Dark-necked Tailorbird Orthotomus atrogularis & $\mathrm{R}$ & 242 \\
\hline Greater Racket-tailed Drongo Dicrurus paradiseus & $\mathrm{R}$ & 196 \\
\hline Asian Glossy Starling Aplonis panayensis & $\mathrm{R}$ & 134 \\
\hline Olive-winged Bulbul Pycnonotus plumosus & $\mathrm{R}$ & 93 \\
\hline Crimson Sunbird Aethopyga siparaja & $\mathrm{R}$ & 83 \\
\hline Orange-bellied Flowerpecker Dicaeum trigonostigma & $\mathrm{R}$ & 56 \\
\hline Asian Fairy-bluebird Irena puella* & $\mathrm{R}$ & 53 \\
\hline Banded Woodpecker Chrysophlegma miniaceum & $\mathrm{R}$ & 45 \\
\hline Common Hill Myna Gracula religiosa* & $\mathrm{R}$ & 45 \\
\hline Blue-winged Leafbird Chloropsis cochinchinensis* & $\mathrm{R}$ & 42 \\
\hline "Pale-rumped Swiftlets" Collocalia spp. & $\mathrm{R}$ & 26 \\
\hline Pink-necked Green Pigeon Treron vernans & $\mathrm{R}$ & 20 \\
\hline Changeable Hawk-Eagle Nisaetus cirrhatus ${ }^{* *}$ & $\mathrm{R}$ & 18 \\
\hline Little Spiderhunter Arachnothera longirostra & $\mathrm{R}$ & 17 \\
\hline Asian Red-eyed Bulbul Pycnonotus brunneus** & $\mathrm{R}$ & 16 \\
\hline Drongo Cuckoo Surniculus lugubris** & $\mathrm{R}$ & 15 \\
\hline Short-tailed Babbler Malacocincla malaccensis\# & $\mathrm{R}$ & 14 \\
\hline Arctic Warbler Phylloscopus borealis & M & 13 \\
\hline Rufous-tailed Tailorbird Orthotomus sericeus & $\mathrm{R}$ & 13 \\
\hline
\end{tabular}

Key: R- Resident; M- Migrant; V - Non-breeding Visitor Other symbols as in Table 1. 
Table 3. Top 20 most abundant birds at Bukit Timah Nature Reserve, derived from results of the Annual Bird Census 1997-2015

\begin{tabular}{|c|c|c|}
\hline Species & Status & Total counted \\
\hline Asian Glossy Starling Aplonis panayensis & $\mathrm{R}$ & 367 \\
\hline Javan Myna Acridotheres javanicus\#\# & $\mathrm{R}$ & 220 \\
\hline Dark-necked Tailorbird Orthotomus atrogularis & $\mathrm{R}$ & 215 \\
\hline Pin-striped Tit-Babbler Macronous gularis & $\mathrm{R}$ & 208 \\
\hline Greater Racket-tailed Drongo Dicrurus paradiseus & $\mathrm{R}$ & 204 \\
\hline Olive-winged Bulbul Pycnonotus plumosus & $\mathrm{R}$ & 127 \\
\hline Asian Fairy-bluebird Irena puella* & $\mathrm{R}$ & 106 \\
\hline Banded Woodpecker Chrysophlegma miniaceum & $\mathrm{R}$ & 102 \\
\hline Black-naped Oriole Oriolus chinensis & $\mathrm{R}$ & 83 \\
\hline Pink-necked Green Pigeon Treron vernans & $\mathrm{R}$ & 82 \\
\hline Crimson Sunbird Aethopyga siparaja & $\mathrm{R}$ & 79 \\
\hline Common Hill Myna Gracula religiosa* & $\mathrm{R}$ & 78 \\
\hline Blue-throated Bee-eater Merops viridis & $\mathrm{R}$ & 73 \\
\hline Little Spiderhunter Arachnothera longirostra & $\mathrm{R}$ & 61 \\
\hline Yellow-vented Bubul Pycnonotus goiavier & $\mathrm{R}$ & 56 \\
\hline Ashy Minivet Pericrocotus divaricatus & $\mathrm{R}$ & 54 \\
\hline Orange-bellied Flowerpecker Dicaeum trigonostigma & $\mathrm{R}$ & 46 \\
\hline Common Iora Aegithina tiphia & $\mathrm{R}$ & 44 \\
\hline White-crested Laughingthrush Garrulax leucolophus & $\mathrm{R}$ & 44 \\
\hline Straw-headed Bulbul Pycnonotus zeylanicus\#\#** & $\mathrm{R}$ & 42 \\
\hline
\end{tabular}

Key: R- Resident; M- Migrant; V - Non-breeding Visitor Other symbols as in Table 1. 
Looking at the four transects, the summit road and Cave Path both have eight nationally threatened species while South View Path and Lasia Track both have five species. It is also noteworthy that South View Path holds all three species of leafbird.

\section{Discussion}

The overall diversity of birds detected was observed to be lower than that recorded during the 1997 survey when 114 species were recorded in BTNR (Lim, 1997). The number of bird species detected in the present survey was 68 . The 46 species detected in 1997 survey but not in the 2016 survey are listed in Table 4.

New for the reserve are the Red Junglefowl Gallus gallus and Blue-eared Kingfisher Alcedo meninting. Also new to the overall list for the Central Catchment and Bukit Timah is the Lineated Barbet Megalaima lineata, an introduced species which is now present in the fringes of BTNR and its buffer zones.

Some of the observed differences in the number of species sighted are attributed to the different methodologies used in the 1996-1997 survey, the current survey and the Annual Bird Census of Nature Society (Singapore) (Table 5).

Of the 46 undetected species, four are nocturnal species, not unexpected as nocturnal surveys were not carried out during this current exercise. In addition, half of the undetected species are migrants, which due to their transient nature, may be missed during a transect-based survey of trails.

Nineteen of the undetected species are resident and these included the following species of conservation interest: Crested Goshawk Accipiter trivirgatus, Barred Eagle-Owl Bubo sumatranus, Scarlet Minivet Pericrocotus speciosus and Chestnut-winged Babbler Stachyris erythroptera.

No immediate explanation is available for the differences between the four transects. The species totals and individuals observed do not correlate readily with the condition of the forest, amount of disturbance, proximity to the forest margin, or ease of visibility. As the remaining forest is small, possibly an individual bird's home range might span several vegetation zones

\section{Comparison with Annual Bird Census $(A B C)$ data}

The NSS's Bird Group has been conducting its own census, the Annual Bird Census (ABC) of different sites throughout Singapore since 1986. One of these key sites is Bukit Timah Nature Reserve. Reviewing the data from 1997 to 2015, we see an average of 159 birds counted annually, with numbers ranging from 51 to 247 birds (Fig. 8). This is much higher than the 32 to 41 average seen from the four transects in 2015-2016. This comparison is made bearing in mind that the transect used for the $\mathrm{ABC}$ at BTNR is approximately $3 \mathrm{~km}$ long and three times the length of the current transects and the time period of the ABC data collection was over 19 years as opposed to 1 year of the current survey (Table 5). 
Table 4. List of bird species present in 1996-1997 survey but not detected in the 2015-2016 survey.

\begin{tabular}{|c|c|}
\hline Species & Status \\
\hline Crested Honey Buzzard Pernis ptilorhynchus & M \\
\hline Black Baza Aviceda leuphotes & M \\
\hline Crested Goshawk Accipiter trivirgatus & $\mathrm{R}$ \\
\hline Chinese Sparrowhawk Accipiter soloensis & M \\
\hline Jambu Fruit Dove Ptilinopus jambu & $\mathrm{V}$ \\
\hline Chestnut-winged Cuckoo Clamator coromandus & M \\
\hline Asian Koel Eudynamys scolopacea & $\mathrm{R}$ \\
\hline Large Hawk-Cuckoo Hierococcyx sparverioides & M \\
\hline Malaysian Hawk-Cuckoo Hierococcyx fugax & V \\
\hline Hodgson's Hawk-Cuckoo Hierococcyx nisicolor & M \\
\hline Indian Cuckoo Cuculus micropterus & M \\
\hline Sunda Scops Owl Otus lempiji & $\mathrm{R}$ \\
\hline Barred Eagle-Owl Bubo sumatranus & $\mathrm{R}$ \\
\hline Brown Hawk-Owl Ninox scutulata & $\mathrm{R}$ \\
\hline Large-tailed Nightjar Caprimigulgus macrurus & $\mathrm{R}$ \\
\hline Grey-rumped Treeswift Hemiprocne longipennis & $\mathrm{R}$ \\
\hline Silver-backed Needletail Hirundapus cochinchinensis & M \\
\hline Brown-backed Needletail Hirundapus giganteus & $\mathrm{V}$ \\
\hline Asian Palm Swift Cypsiurus balasiensis & $\mathrm{R}$ \\
\hline Pacific Swift Apus pacificus & M \\
\hline House Swift Apus nipalensis & $\mathrm{R}$ \\
\hline Ruddy Kingfisher Halcyon coromanda & M \\
\hline White-throated Kingfisher Halcyon smyrnensis & $\mathrm{R}$ \\
\hline
\end{tabular}


Table 4. Continuation.

\begin{tabular}{|c|c|}
\hline Species & Status \\
\hline Collared Kingfisher Todiramphus chloris & $\mathrm{R}$ \\
\hline Oriental Dwarf Kingfisher Ceyx erithaca & M \\
\hline Blue-tailed Bee-eater Merops philippinus & M \\
\hline Sunda Pygmy Woodpecker Dendrocopus moluccensis & $\mathrm{R}$ \\
\hline Laced Woodpecker Picus vittatus & $\mathrm{R}$ \\
\hline Peregrine Falcon Falco peregrinus & M \\
\hline Hooded Pitta Pitta sordida & M \\
\hline Blue-winged Pitta Pitta moluccensis & M \\
\hline Golden-bellied Gerygone Gerygone sulphurea & $\mathrm{R}$ \\
\hline Common Iora Aegithina tiphia & $\mathrm{R}$ \\
\hline Ashy Minivet Pericrocotus divaricatus & M \\
\hline Scarlet Minivet Pericrocotus speciosus & $\mathrm{R}$ \\
\hline Malaysian Pied Fantail Rhipidura javanica & $\mathrm{R}$ \\
\hline Blyth's (Asian) Paradise Flycatcher Terpsiphone blythi & M \\
\hline Large-billed Crow Corvus macrorhynchos & $\mathrm{R}$ \\
\hline Streaked Bulbul Hemixos malaccensis & $\mathrm{V}$ \\
\hline Asian House Martin Delichon dasypus & M \\
\hline Red-rumped Swallow Cecropsis daurica & M \\
\hline Yellow-browed Warbler Phylloscopus inornatus & M \\
\hline Chestnut-winged Babbler Stachyris maculatus & $\mathrm{R}$ \\
\hline Daurian Starling Agropsar sturninus & M \\
\hline Yellow-rumped Flycatcher Ficedula zanthopygia & M \\
\hline Mugimaki Flycatcher Ficedula mugimaki & M \\
\hline
\end{tabular}

Key: Status - R - Resident; M - Migrant; V - Non-breeding Visitor. 
Table 5. Comparison of the methodologies used in three surveys of birds in Bukit Timah Nature Reserve.

\begin{tabular}{|l|l|l|l|}
\hline & $\mathbf{1 9 9 6 - 1 9 9 7}$ survey & $\mathbf{2 0 1 5 - 2 0 1 6}$ survey & *NSS ABC 1997-2015 \\
\hline Period of survey & $1 \mathrm{yr}$ & $1 \mathrm{yr}$ & $19 \mathrm{yrs}$ \\
\hline Survey time & $\begin{array}{l}\text { Diurnal: } \\
0830-0930 \mathrm{hrs} \\
\text { Nocturnal: } \\
1930-2130 \mathrm{hrs}\end{array}$ & $\begin{array}{l}\text { Diurnal: } \\
0730-0830 \mathrm{hrs} \\
\text { No nocturnal } \\
\text { surveys }\end{array}$ & Diurnal \\
\hline $\begin{array}{l}\text { Line transects } \\
\text { Survey } \\
\text { methodology }\end{array}$ & $\begin{array}{l}\text { - Aural/visual } \\
\text { counting } \\
\text { Mist-netting }\end{array}$ & $\begin{array}{l}\text { - Aural/visual } \\
\text { counting } \\
\text { ・ No mist-netting }\end{array}$ & $\bullet$ Aural/visual counting \\
\hline
\end{tabular}

* NSS ABC: Nature Society (Singapore), Annual Bird Census.

The number of species recorded during the census at BTNR from 1997 to 2015 is 87 . The average number of species is 35 species and varies from 14 to 44 (Fig. 9). A typical current transect, e.g. Summit Road, recorded 5-19 species

Both bird diversity and abundance are lower than the 1996-1997 survey and the ABC of 1997-2015. To ensure that inferences on trends are based on sound science, data must be collected using similar methodologies. For such complex situations, further research backed up by stringent experimental design would have to be carried out to ascertain and determine the key factors contributing to these observations. Some of the issues pertaining to the long-term conservation of bird diversity in BTNR that need to be investigated include, 1) the impact of human visitorship, 2) edge effects, 3) isolation and fragmentation of BTNR from CCNR by roads and other infrastructure, 4) genetic isolation and erosion that occurred for species such as White-bellied Woodpecker Dryocopusjavensis, lastrecorded in 1992, and Scarlet Minivet Pericrocotus speciosus, last recorded in 2001, and 5) inroads made by adaptable non-forest species like Lesser Coucal Centropus bengalensis and Yellow-vented Bulbul Pycnonotus goiavier and their effects on BTNR's birdlife, in particular its forest specialists.

If we look at the presence of key species, defined by Lim (1997) as species that are both nationally threatened and predominantly forest stenotopics, we see an identical count of eight species for both the 1996-1997 and the 2015-C2016 surveys. Comparing the two lists, the 1996-1997 survey had two species undetected during the 2015-2016 survey: Scarlet Minivet Pericrocotus speciosus and Chestnut-winged Babbler Stachyris erythtroptera. Conversely, the 2015-2016 survey had the following species that were not observed during from the 1996-1997 list: 


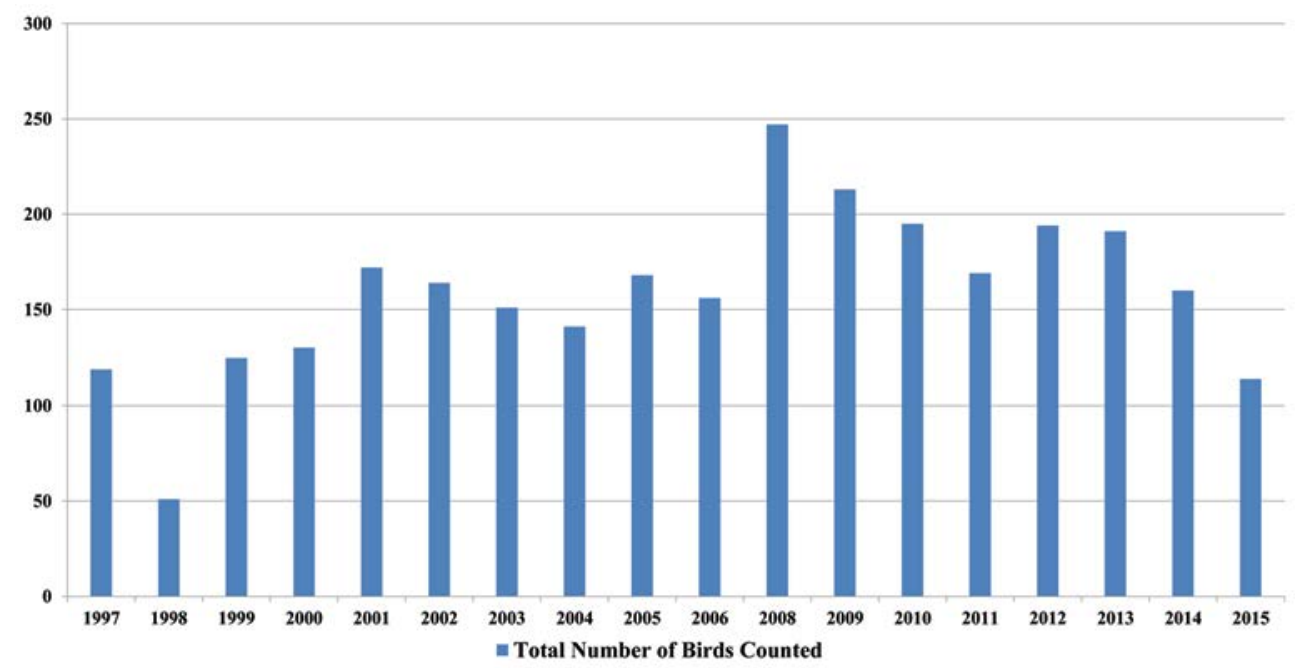

Fig. 8. Total number of birds recorded at Bukit Timah Nature Reserve during the Annual Bird Census, 1997-2015. (Data: Nature Society, Singapore).

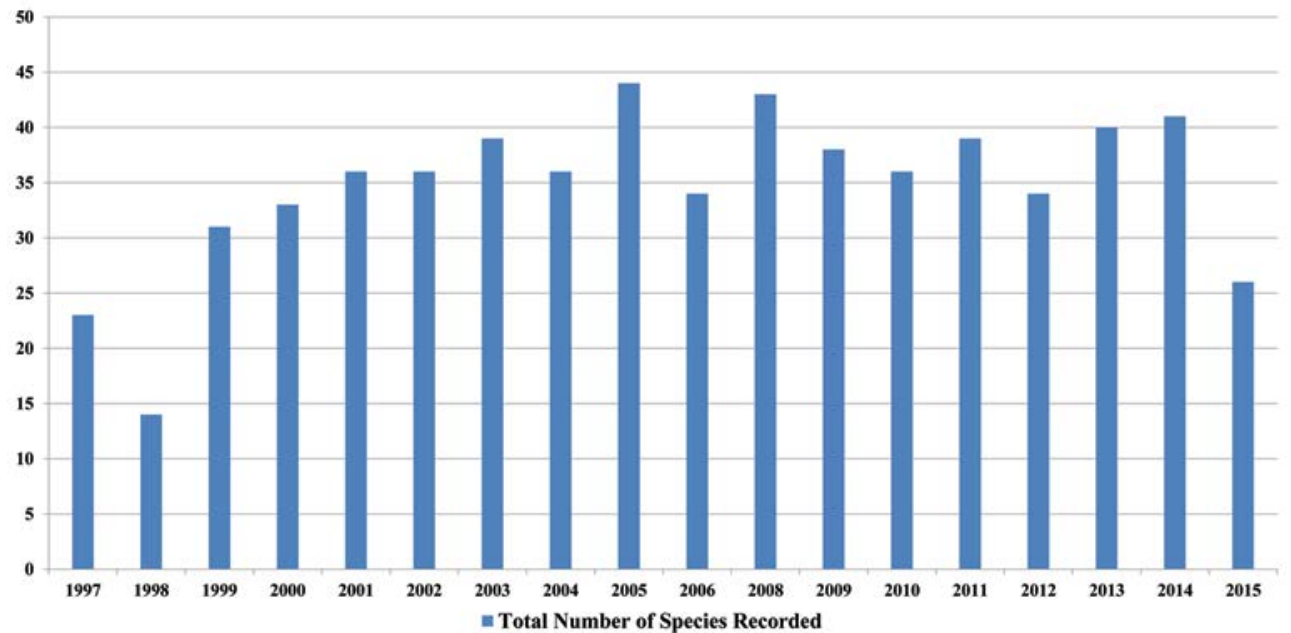

Fig. 9. Total number of species recorded at Bukit Timah Nature Reserve during the Annual Bird Census, 1997-2015. (Data: Nature Society, Singapore).

Blue-eared Kingfisher Alcedo meninting and Plume-toed Swiftlet Collocalia affinis. It is noteworthy that this indicates that while overall diversity of species in the present survey may have been lower than the 1996-1997 survey or the 1997-2015 Annual Bird Census, the number of key species has remained constant. 


\section{Annotated checklist of selected species}

Red Junglefowl, Gallus gallus

Terrestrial granivore of coastal vegetation and forest margins native to Southeast Asia; nationally threatened. A new addition to the checklist for the central forests. Origin doubtful but human intervention is suspected here as well as in other parts of Singapore. Breeding recorded.

Changeable Hawk-Eagle, Nisaetus cirrhatus

Diurnal forest raptor; nationally threatened. The population appears stable at BTNR and prospects are good for this species in Singapore as urban parks and remnant woodland have been shown to be used by this species for nesting. Breeding recorded.

Crested Goshawk, Accipiter trivirgatus

Diurnal forest raptor; nationally threatened. This species was not detected in the 2015 2016 survey but its national population is increasing with breeding success all over Singapore and even in urban parks such as Ang Mo Kio Town Garden West and in a carpark in Bedok Estate. Breeding recorded.

Red-legged Crake, Rallina fasciata

Terrestrial forest omnivore; nationally threatened. This species was not detected during the 2015-2016 survey but is regularly seen at Hindhede Nature Park. Nationally, it appears to be not uncommon in wooded and garden habitats throughout Singapore. Breeding recorded.

Thick-billed Green Pigeon, Treron curvirostra

Frugivore favouring forests but subject to local movements; nationally threatened. The population appears stable. This species was present in both surveys. Sightings are regular within the central forests especially at suitable fruiting trees. Breeding recorded.

Chestnut-bellied Malkoha, Phaenicophaeus sumatranus

Arboreal insectivore; globally and nationally near-threatened. Present in both surveys and population appears to be increasing countrywide. Range expansions have been observed in the past decade with the species now recorded in several localities in western Singapore, e.g. Kent Ridge Park, Jurong Eco Garden. Breeding recorded.

Violet Cuckoo, Chrysococcyx xanthorhynchus

Insectivore occurring mainly in forests at canopy level; nationally threatened. The population appears stable. This species was present in both surveys. Breeding recorded.

Rusty-breasted Cuckoo, Cacomantis sepulcralis

Insectivore occurring mainly in forests; nationally threatened. The population appears stable. Breeding recorded. 
Drongo Cuckoo, Surniculus lugubris

Insectivore occurring mainly in forests; nationally threatened. The population appears stable. This species was present in both surveys. Breeding recorded.

Barred Eagle-Owl, Bubo sumatranus

Nocturnal carnivore; nationally threatened. This species was not detected in the 20152016 survey. It is currently known to occur in both BTNR and CCNR with another population in Pulau Ubin. The population trend is not known. Breeding recorded (Pulau Ubin).

Plume-toed Swiftlet, Collocalia affinis

Aerial insectivore occurring mainly in forests; nationally threatened. The population appears to be increasing. It has recently been recorded at various sites outside the forest including the Singapore Botanic Gardens and Bishan-Ang Mo Kio Park. Breeding recorded.

Blue-eared Kingfisher, Alcedo meninting

Forest piscivore previously confined to CCNR but found to be present in a small wetland within BTNR. Needs further monitoring. Breeding recorded (at CCNR).

Red-crowned Barbet, Megalaima rafflesii

Forest insectivore; globally and nationally near-threatened. The population appears to be stable. This species was present in both surveys. Breeding recorded.

White-bellied Woodpecker Dryocopus javensis

Forest insectivore; nationally threatened. There have been no sightings in BTNR since 1992. Breeding not recorded.

Blue-rumped Parrot, Psittinus cyanurus

Forest frugivore subject to local movements; nationally threatened and globally near-threatened. This species was present in both surveys. The population appears to be stable. Breeding not recorded.

Long-tailed Parakeet, Psittacula longicauda

Forest frugivore; globally near-threatened. The population appears stable despite competition with introduced parakeets. This species was present in both surveys. Wanders widely but most often encountered in the central forests and in the north of Singapore. Breeding recorded.

Blue-crowned Hanging Parrot, Loriculus galgulus

Frugivore found in forest, wooded areas and gardens and subject to local movements; nationally threatened. This species was present in both surveys. In view of its increase in both range and abundance within Singapore, this species should perhaps be 
de-listed. Recent observations have shown that it is able to nest in urban parks and even car-parks. Breeding recorded.

Lesser Cuckooshrike, Coracina fimbriata

Forest insectivore; nationally threatened. Population unknown. No records since 1986; Bukit Timah Nature Reserve was the only locality in Singapore from which the species had previously been recorded. Breeding not recorded.

\section{Scarlet Minivet, Pericrocotus speciosus}

Forest insectivore; nationally threatened. This species was not recorded during the 2015-2016 survey. The last record from BTNR was in 2001 when one bird was detected during an NSS census. Breeding not recorded.

\section{Straw-headed Bulbul, Pycnonotus zeylanicus}

Frugivore of forests and wooded areas; globally and nationally threatened due to the regional caged birds trade. The population is stable and increasing (Yong et al., 2017). Birds at BTNR are usually recorded at the Mountain Biking Trail and adjoining buffer zones such as Hindhede Nature Park and Dairy Farm Nature Park. In view of its status as a globally endangered species, it would be pertinent to maintain patrols of areas where the birds occur to prevent poaching. Breeding recorded.

\section{Cream-vented Bulbul, Pycnonotus simplex}

Forest frugivore; nationally near-threatened. This species was present in both surveys. the population appears to be stable but it is a stenotopic forest species and may require further monitoring. Breeding recorded.

Asian Red-eyed Bulbul, Pycnonotus brunneus

Forest frugivore; nationally threatened. The population appears stable. This species was present in both surveys. Breeding recorded.

\section{Buff-vented Bulbul, Iole olivacea}

Forest insectivore; nationally threatened. This species was not detected in both surveys and was last recorded at BTNR in 1991. Population unknown. Breeding not recorded.

Chestnut-winged Babbler, Stachyris erythroptera

Forest insectivore; nationally threatened. This species was not detected in the 20152016 survey. The population trend at BTNR is unclear. Breeding recorded (CCNR).

Short-tailed Babbler, Malacocincla malaccensis

Forest insectivore frequenting the forest floor and undergrowth; globally nearthreatened. This species was detected in both surveys. Presence easily detected by their loud diagnostic calls. The population appears stable.

Asian Fairy-bluebird, Irena puella 
Forest frugivore; nationally near-threatened. This species occurs only in the central forests. Present in both surveys and population appears stable. Breeding not recorded.

\section{Common Hill Myna, Gracula religiosa}

Forest frugivore; nationally near-threatened. This species occurs in the central forests as well as other parts of Singapore including Sentosa and Pulau Ubin. Present in both surveys and population appears to be stable. Breeding not recorded.

\section{Javan Myna, Acridotheres javanicus}

Generalist found in most habitats; listed by IUCN as Vulnerable due to illegal trapping in its original range in Java and Bali. In Singapore, this is our most abundant bird and under no threat. In fact, the then Agri-Veterinary Authority (AVA) had considered this species a pest. Breeding recorded.

Brown-chested Jungle-flycatcher, Cyornis brunneatus

Insectivore inhabiting forests and scrub; globally threatened due to deforestation in both its breeding and wintering grounds. In Singapore, this species is an uncommon passage migrant and winter visitor most often seen in wooded habitats from September to March. Present in both BTNR and CCNR.

White-rumped Shama, Copsychus malabaricus

Forest insectivore; nationally threatened. This species occurs in the central forests, Pulau Ubin and Pulau Tekong Besar. It was not detected in both surveys but recorded in the census conducted by NSS. Breeding recorded (CCNR).

Greater Green Leafbird, Chloropsis sonnerati

Forest frugivore of the canopy; globally and nationally threatened. The population appears stable. This species was present in both surveys. Breeding recorded.

Lesser Green Leafbird, Chloropsis cyanopogon

Forest frugivore of the canopy; globally and nationally threatened. The population appears stable. This species was present in both surveys. Breeding recorded.

Blue-winged Leafbird, Chloropsis cochinchinensis

Forest frugivore; nationally near-threatened. This species was recorded in both surveys and is our most common leafbird. The population appears stable. Breeding recorded.

Yellow-vented Flowerpecker, Dicaeum chrysorrheum

Forest frugivore; nationally threatened. This species was absent in both surveys. The population trend is unknown. It was last recorded in 2012. Breeding not recorded. 


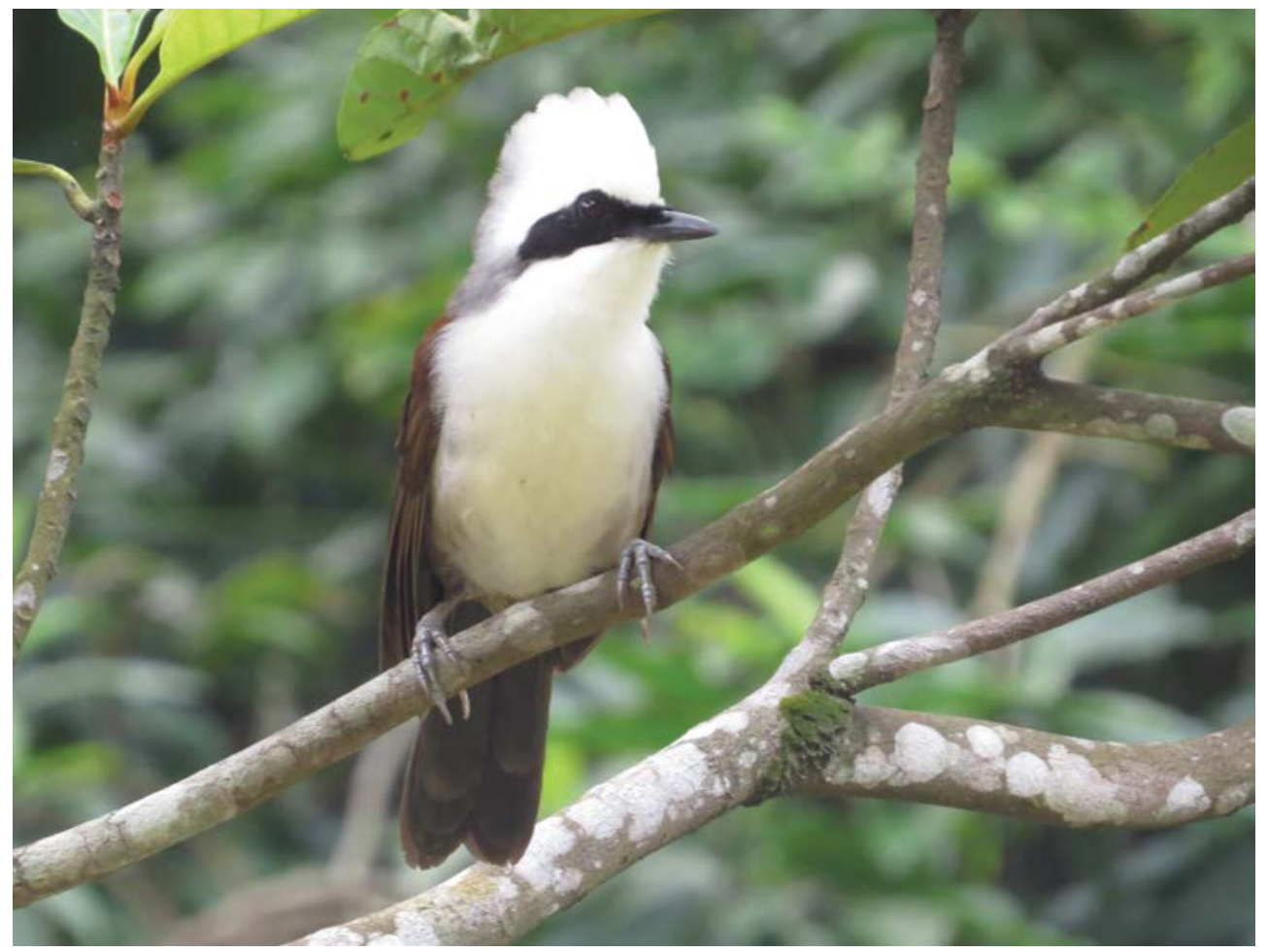

Fig. 10. The White-crested Laughingthrush Garrulax leucolophus is a non-native species making inroads into the nature reserve. Active management may be required to contain this threat (Photo: K.S. Lim).

\section{Conclusion}

BTNR is vital to the conservation of forest species in Singapore, both resident and migratory.

Isolation and fragmentation are serious problems for the populations that are present in BTNR and the situation needs to be monitored and mitigated. Adding buffer zones and faunal connectors such as the Eco-link@BTNR are useful measures to protect its integrity and should be continued. Other serious issues are the increasing number of introduced and invasive species found in the nature reserves, e.g. White-crested Laughingthrush Garrulax leucolophus (Fig. 10), and opportunistic poaching for the cagebird trade, e.g. Straw-headed Bulbul Pycnonotus zeylanicus. Lastly, species management plans, inclusive of re-introduction programmes, could be drawn up to protect the species that show obvious signs of decline, especially stenotopic forest species that are also nationally or globally threatened. All of the above point to the urgent need for continuous survey and research to establish a clearer understanding of the avian ecology within BTNR, so that conservation and management plans could be enhanced. 


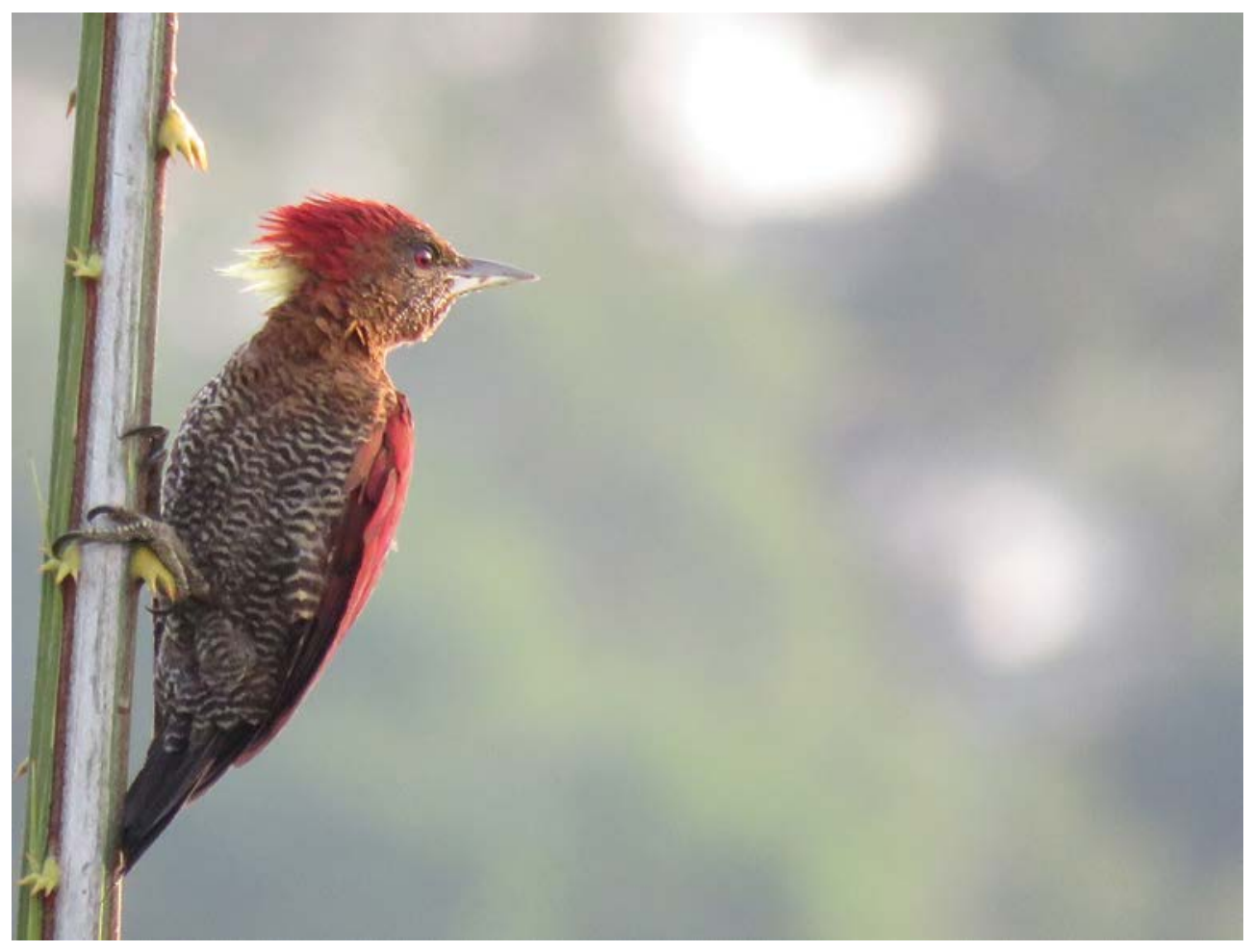

Fig. 11. The Banded Woodpecker Chrysophlegma miniaceum is the most abundant woodpecker in the nature reserve (Photo. K.S. Lim).

ACKNOWLEDGMENTS. We would like to thank the National Parks Board for the opportunity to participate in this survey of the birds of Bukit Timah Nature Reserve, especially Dr Lena Chan and Low Bing Wen. Thanks are due to my fellow field participants, viz. Dr Ho Hua Chew, Lim Kim Keang, Low Bing Wen and Alan Owyong. Thanks are also due to Lim Kim Chuah for access to Nature Society (Singapore) Bird Group data on the Annual Bird Census. Without their hard work, cooperation and commitment, this report would never have been accomplished.

\section{References}

Chan, L. \& Davison, G.W.H. (2019). Introduction to the Comprehensive Biodiversity Survey of Bukit Timah Nature Reserve, Singapore, 2014-2018. Gard. Bull. Singapore 71 (Suppl. 1): 3-17.

Lim, K.S. (1992). Vanishing birds of Singapore. Singapore: The Nature Society (Singapore).

Lim, K.S. (1997). Bird Biodiversity in the Nature Reserves of Singapore. Proceedings of the Nature Reserves Survey Seminar. Gard. Bull. Singapore 49: 225-244.

Lim, K.S. (2018). Checklist of the Birds of Singapore. Singapore: The Nature Society (Singapore) Bird Group Records Committee. 
Lim, K.S., Ho, H.C., Lim, K.K., Lim, K.C., Wang, L.K. \& Davison, G. (2008). Birds. In: Davison, G.W.H., Ng, P.K.L. \& Ho, H.C. (eds) The Singapore Red Data Book: Threatened Plants and Animals of Singapore, $2^{\text {nd }}$ ed., pp. 177-189. Singapore: The Nature Society (Singapore).

Yong, D.L., Lim, K.S., Lim, K.C., Tan, T., Teo, S. \& Ho, H.C. (2017). Significance of the globally threatened Straw-headed Bulbul Pycnonotus zeylanicus populations in Singapore: a last straw for the species? Bird Conserv. Int. 28(1): 133-144. 